\title{
Geriatric Nutrition in Denture Wearers: Revisited
}

\author{
${ }^{1}$ Meenakshi S Iyer, ${ }^{2}$ Sanjana Madarapu, ${ }^{3} \mathrm{KN}$ Raghavendra Swamy
}

\begin{abstract}
The prevalence of malnutrition increases with age because of many factors. Presence of edentulous jaws leads to avoidance of many types of food. Shifts in food selection patterns result from impairments in masticatory ability. In most of the instances, prosthodontic treatment alone, such as complete dentures, implant overdentures, or other prosthetic treatment for elderly patients in the absence of proper dietary instructions, is inadequate to attain a significant progress in nutritional levels. Thus, to achieve a successful therapy, most researchers imply on giving a dietary instruction as a part of treatment procedure. An attempt has been made to review the dietary requirements for geriatric denture wearers which would benefit them from untoward consequences of malnutrition.
\end{abstract}

Keywords: Dentures, Food pyramid, Geriatric denture wearers, Minerals recommended daily allowance, Nutrition, Vitamins.

How to cite this article: lyer MS, Madarapu S, Swamy KNR. Geriatric Nutrition in Denture Wearers: Revisited. J Oral Health Comm Dent 2018;12(2):47-50.

Source of support: Nil

Conflict of interest: None

\section{INTRODUCTION}

The goal of every individual is to lead a long and healthy life. With our groundbreaking medical achievements, we have managed to increase the average life expectancy, but the quality of life during geriatric age continues to detoriate. ${ }^{1}$ During this period, our body undergoes physiological changes which lead to increased susceptibility toward many diseases. All the fatal diseases in modern world like diabetes, hypertension, atherosclerosis, etc., mostly result due to poor nutrition or "malnutrition."

\footnotetext{
${ }^{1}$ Senior Lecturer, ${ }^{2}$ Student (Third Year), ${ }^{3}$ Professor

${ }^{1-3}$ Department of Prosthodontics, J.S.S. Dental College \& Hospital, Jagadguru Sri Shivarathreeshwara University, Mysuru Karnataka, India

Corresponding Author: Meenakshi S Iyer, Senior Lecturer Department of Prosthodontics, J.S.S. Dental College \& Hospital Jagadguru Sri Shivarathreeshwara University, Mysuru, Karnataka India, Phone: +919886494066, e-mail: itsprosthodontist@ gmail.com
}

\section{What is Malnutrition $?^{2}$}

Malnutrition is defined as "a state of nutrition in which a deficiency or excess (or imbalance) of energy, protein and other nutrients causes measurable adverse effects on tissue/body form (body shape, size, and composition) and function, and clinical outcome." Many nutritional deficiencies show oral manifestations which serve as good soil for many pathologies.

\section{Nutrition in Denture Wearers $\mathbf{s}^{3,4}$}

In patients with complete tooth loss, prosthetic therapy not only restores the teeth but also installs confidence in them. The longevity and stability of this complete denture prosthesis depend on patients' mucosal health. Any change in mucosa leads to ill-fitting dentures and thus failure of treatment. Mucosal health is determined by the type of food a person consumes. Edentulous individuals consume lower amounts of protein and other nutrients, including fibers, carbohydrates, and some vitamins, because they avoid ample food types, especially fresh fruits and uncooked vegetables when compared with other groups of population. An understanding of the nutritional requirements, symptoms of malnutrition, and environmental factors that influence food choices will assist the prosthodontist in identifying the denture-wearing patients at risk of malnutrition. Dietary guidance and nutritional support will improve the tolerance of the oral mucosa to new dentures and prevent the rejection of dentures. Since denture fabrication requires a series of appointments, dietary analysis and counselling can be easily incorporated into an edentulous patient's treatment plan.

\section{Factors influencing Malnutrition in Elderly ${ }^{5-8}$}

\section{Patient Factors}

- The food choices of patient may be altered due to

- Fear of food lodgment

- Fear of choking

- Hysteria

- Some people tend to compensate for decline in masticatory ability by choosing cooked or processed food over fresh food which creates a nutritional imbalance.

- Most of the elders these days are under many medications which may cause anorexia, nausea, gastrointestinal disturbances, and interfere with nutrient absorption and utilization. 


\section{Physiologic Factors ${ }^{9,10}$}

- Muscular forces decrease as age progresses which leads to increase in duration and force applied during mastication.

- Decrease in quantity of saliva is seen with advancing age. Therefore, the ability to form a bolus which assists easy swallowing (plastic, cohesive and slippery) is hampered.

- Dehydration: This is a result of impaired water absorption by the kidneys. Kidneys are one of the primary organs which start degenerating as the age increases. Disturbances in kidney function not only cause dehydration but also invite many other deadly conditions like hyponatremia, hypoglycemia, etc. Aging processes has detrimental effects on nutritional status, nutrient requirements of the elderly. The factors affecting dietary intake will help the prosthodontist to provide appropriate meaningful guidance to the geriatric individuals in achieving improved oral health (Tables 1 and 2).

\section{Diet Recommended for a New Denture Wearer ${ }^{17,18}$}

The regularly followed procedure of eating food is ingestion, mastication, and swallowing/deglutition. For a new denture wearer, it is much easier to just swallow the food. As the patient tends to swallow food in their first days' postinsertion, it becomes mandatory to put the patient on a proper liquid diet until they get accustomed to the new prosthesis. Once the oral cavity of the patient shows significant improvement without any allergic reactions toward the given prosthesis, a solid and firm diet can be followed.

Table 1: Nutrient needs of elderly individuals ${ }^{11-16}$

\begin{tabular}{|c|c|c|}
\hline Vitamin & $\begin{array}{l}\text { Recommended daily } \\
\text { allowance }\end{array}$ & Deficiency manifestations \\
\hline \multirow[t]{3}{*}{ Vitamin A } & $800-1000 \mu \mathrm{g} /$ day & $\begin{array}{l}\text { Dryness and keratosis of } \\
\text { oral mucosa }\end{array}$ \\
\hline & & Decreased salivary flow \\
\hline & & Hyperplasia of gums \\
\hline $\begin{array}{l}\text { Thiamine } \\
\text { (vitamin } \mathrm{B}_{1} \text { ) }\end{array}$ & $1 \mathrm{mg} / \mathrm{day}$ & Beri-beri \\
\hline Vitamin $\mathrm{B}_{6}$ & $1.2-1.4 \mathrm{mg} / \mathrm{day}$ & Severe glossitis \\
\hline \multirow[t]{2}{*}{ Vitamin $\mathrm{B}_{12}$} & 8 mg/day & Magenta-colored tongue \\
\hline & & Glossodynia \\
\hline Vitamin D & $5 \mu \mathrm{g} / \mathrm{day}$ & - \\
\hline Vitamin $\mathrm{E}$ & $\begin{array}{l}\text { Total plasma levels } \\
\text { increase with age }\end{array}$ & Deficiency is rare \\
\hline Vitamin C & $60 \mu \mathrm{g} /$ day & Spongy bleeding gums \\
\hline \multirow[t]{3}{*}{ Folic acid } & $500 \mu \mathrm{g} /$ day & Mouth ulcers \\
\hline & & Glossodynia \\
\hline & & Stomatitis and glossitis \\
\hline
\end{tabular}

Table 2: Recommended daily allowance (RDA) of minerals

\begin{tabular}{|c|c|c|}
\hline & $R D A$ & $\begin{array}{l}\text { Deficiency } \\
\text { manifestations }\end{array}$ \\
\hline \multicolumn{3}{|l|}{ Mineral } \\
\hline Calcium & 800 mg/day & $\begin{array}{l}\text { Alveolar ridge resorption } \\
\text { Osteoporosis }\end{array}$ \\
\hline Iron & 10 mg/day & $\begin{array}{l}\text { Burning tongue } \\
\text { Anemia } \\
\text { Angular cheilitis }\end{array}$ \\
\hline Zinc & 15 mg/day & $\begin{array}{l}\text { Decreased taste } \\
\text { sensation } \\
\text { Delayed wound healing }\end{array}$ \\
\hline \multicolumn{3}{|l|}{ Component } \\
\hline Energy & $\begin{array}{l}65 \text { - to } 74 \text {-year-old } \\
\text { female: } 1300 \mathrm{kcal} / \mathrm{day} \\
65 \text { - to } 74-y e a r-o l d \\
\text { male: } 1800 \mathrm{kcal} / \mathrm{day}\end{array}$ & $\begin{array}{l}\text { Parotid gland } \\
\text { enlargement } \\
\text { Muscle wasting } \\
\text { Pale and atrophic tongue }\end{array}$ \\
\hline Protein & $\begin{array}{l}56 \mathrm{gm} / \text { day male } \\
46 \mathrm{gm} / \text { day female }\end{array}$ & edema \\
\hline Carbohydrates & $\begin{array}{l}50-60 \% \text { of total } \\
\text { calories consumed } \\
\text { per day }\end{array}$ & Deficiency is rarely seen \\
\hline Water & $30 \mathrm{~mL} / \mathrm{kg}$ body wt/day & Xerostomia \\
\hline Calories & $\begin{array}{l}1600 \mathrm{kcal} / \text { day female } \\
2400 \mathrm{kcal} / \text { day male }\end{array}$ & $\begin{array}{l}\text { Decreased masticatory } \\
\text { ability }\end{array}$ \\
\hline
\end{tabular}

\section{First Postinsertion Day}

Vegetable-Fruit group: Fruit or vegetable juices are advised. In addition to providing necessary nutrients, juices also produce a soothing effect in the oral cavity of the patient. Bread-Cereal group: Softened bread or cereals mixed in liquid consistency can be recommended to maintain protein levels of the body. Milk group: Fluid milk is included in the dietary pattern which serves as rich source of calcium and prevents conditions like osteoporosis. Meat group: Meats made into puree form, meat broths or soups which are more palatable and easier to swallow can be instructed. As the geriatric age group is more prone to physiologic muscle loss and bone resorption, two glasses of milk has to be added to the dietary menu to prevent osteoporosis.

\section{Second and Third Postinsertion Day}

Vegetable-Fruit group: Juices; seedless and peeled vegetables, fruits cooked in semi-solid consistency. Bread-cereal group: Cooked cereals, rice porridge, soft noodles or pasta, crushed bread powder with milk. Milk group: Milk and melted cottage cheese can be directly consumed. Meat group: Tenderly cooked chicken, finely cut beef, thick broth or soups, fish liver with thick cream, etc. The sample menu must include consumption of any two dairy products (milk, butter, cheese, etc.) at least once a day. 


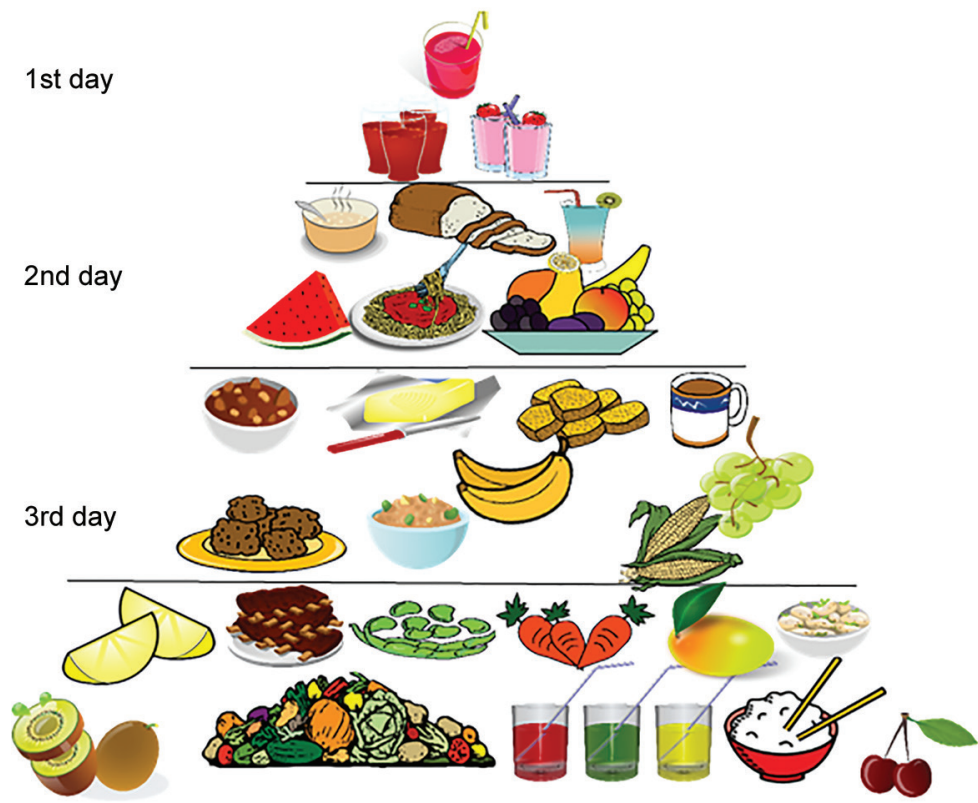

Fig. 1: Food pyramid for geriatric denture wearers



Insertion/recall
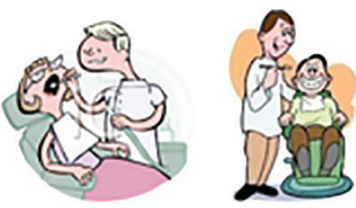
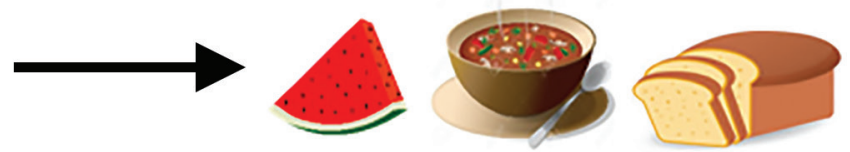

Third day and after

Second day


Fig. 2: Dietary habits for a new denture wearer

\section{Fourth Day and After}

With the usage of dentures together with denture hygiene, the sore spots which were once painful and red creating inconvenience to the patient tend to heal. The patient can shift the dietary needs from soft fluid diet to a solid diet. Care must be taken to prevent gagging or choking. This is done the cutting the food into smaller bits before consumption until the patient gets adapted with the prosthesis (Figs 1 and 2).

\section{RECOMMENDATIONS}

Recommendations can be given to health care providers to highlight about the nutritional status of elderly individual while taking case history. Together with past medical history, nutritional assessment could be made mandatory in the form of mini nutritional assessment tool. The assessment should include intentional/unintentional weight loss/gain, changes in dietary pattern, and type of food eaten and difficulty in eating. Health care professionals should be consistent in providing necessary dietary care or recommendations could be made to a nutrtionist. ${ }^{19}$

Recall visits should be made mandatory for adults with full dentures for their scheduled oral health assessments. Difficulties in chewing and denture discomfort are common with old age. This could further decrease or alter the dietary pattern due to pain and discomfort. Denture alterations are necessary to prevent mucosal abrasions and edema. 
The overall quality of life could be improved by providing proper fitting prostheses with better quality materials.

\section{CONCLUSION}

Complete denture wearers are always at a greater risk of malnutrition than normal population. Regular monitoring of nutritional status of complete denture wearers is important to prevent morbidities and complications associated with malnutrition. Hazards of imbalanced diet, consumption of excessive amount of cariogenic food should be clearly elucidated by the dentist and dietary advice must be given accordingly.

Thus, dietary counseling and analysis should be incorporated into the treatment sequence of fabrication of denture prosthesis.

\section{REFERENCES}

1. Joshipura KJ, Willet WC, Douglass CW. The impact of edentulousness on nutrition and food intake. J Am Dent Assoc 1996 Apr;127(4):459-467.

2. Lochs H, Allison SP, Meier R, Pirlich M, Kondrup J, Schneider S, van den Berghe G, Pichard C. Introductory to the ESPEN Guidelines on enteral nutrition: terminology, definitions and general topics. Clin Nutr 2006 Apr;25(2):180-186.

3. Cousson PY, Bessadet M, Nicolas E, Veyrune JL, Lesourd B, Lassauzay C. Nutritional status, dietary intake and oral quality of life in elderly complete denture wearers. Gerodontology 2012 Jun;29(2):e685-e692.

4. Mishellany-Dutour A, Renaud J, Peyron MA, Rimek F, Woda A. Is the goal of mastication reached in young dentates, aged dentates and aged denture wearers? Br J Nutr 2008 Jan;99(1): 121-128.

5. Nagler RM. Salivary glands and the aging process: mechanicalefficacy monitoring. Biogerontology 2004;5(4):223-233.
6. Nowjack-Raymer RE, Sheiham A. Association of edentulism and diet and nutrition in US adults. J Dent Res 2003 Feb;82(2):123-126.

7. Chauncey HH, Muench ME, Kapur KK, Wayler AH. The effect of the loss of teeth on diet and nutrition. Int Dent J 1984 Jun;34(2):98-104.

8. Ogawa T, Uota M, Ikebe K, Arai Y, KamideK, Gondo Y, Masui Y, Ishizaki $\mathrm{T}$, Inomata $\mathrm{C}$, Takeshita $\mathrm{H}$, et al. Longitudinal study of factors affecting taste sense decline in old-old individuals. J Oral Rehabil 2017 Jan;44(1):22-29.

9. Krall E, Hayes C, Garcia R. How dentition status and masticatory function affect nutrient intake. J Am Dent Assoc 1998 Sep;129(9):1261-1269.

10. N'Gom PI, Woda A. Influence of impaired mastication on nutrition. J Prosthet Dent 2002 Jun;87(6):667-673.

11. Prinz JF, Lucas PW. An optimization model for mastication and swallowing in mammals. Proc Biol Sci 1997 Dec;264(1389):1715-1721.

12. Mese H, Matsuo R. Salivary secretion, taste and hyposalivation. J Oral Rehabil 2007 Oct;34(10):711-723.

13. Budtz-Jørgensen E, Chung JP, Rapin $\mathrm{CH}$. Nutrition and oral health. Best Pract Res Clin Gastroenterol 2001 Dec;15(6):885-896.

14. Bradbury J, Thomason JM, Jepson NJ, Walls AW, Allen PF, Moynihan PJ. Nutrition counseling increases fruit and vegetable intake in the edentulous. J Dent Res 2006 May;85(5):463-468.

15. Adams CD. Gerodontologic aspects of diet and nutrition. J Prosthet Dent 1961 Mar-Apr;11(2):345-348.

16. Brodeur JM, Laaurin D, Vallee R, Lachapelle D. Nutrition intake and gastrointestinal disorders related to masticatory performance in the edentulous elderly. J Prosthet Dent 1993 Nov;70(5):468-473.

17. Detroit M. Nutrition for the denture patient. J Prosthet Dent 1978;40:122-126.

18. Bandodkar KA, Aras M. Nutrition for geriatric denture patients. J Indian Prosthodont Soc 2006 Mar;6(1):22-28.

19. Marshall TA, Warren JJ, Hand JS, Xie XJ, Stumbo PJ. Oral health, nutrition intake and dietary quality in the very old. J Am Dent Assoc 2002 Oct;133(10):1369-1379. 